\title{
Causality Assessment of Olfactory and Gustatory Dysfunction Associated with Intranasal Fluticasone Propionate: Application of the Bradford Hill Criteria
}

\author{
Chandrashekhar S. Muganurmath · Amy L. Curry • Andrew H. Schindzielorz
}

Received: December 7, 2017 / Published online: February 2, 2018

(C) The Author(s) 2018. This article is an open access publication

\begin{abstract}
Causality assessment is crucial to post-marketing pharmacovigilance and helps optimize safe and appropriate use of medicines by patients in the real world. Self-reported olfactory and gustatory dysfunction are common in the general population as well as in patients with allergic rhinitis and nasal polyposis. Intranasal corticosteroids, including intranasal fluticasone propionate (INFP), are amongst the most effective drugs indicated in the treatment of allergic rhinitis and nasal polyposis. While intranasal corticosteroids are associated with olfactory and gustatory dysfunction and are currently labeled for these adverse events, causality assessment has not been performed to date. Although there is no single widely accepted method to assess causality in pharmacovigilance, the Bradford Hill criteria offer a robust and comprehensive approach because nine distinct aspects of an observed potential drug-event association are assessed. In this literature-based narrative review, Hill's criteria were applied to determine
\end{abstract}

Enhanced content To view enhanced content for this article go to https://doi.org/10.6084/m9.figshare. 5798859.

C. S. Muganurmath ( $\square) \cdot$ A. L. Curry ·

A. H. Schindzielorz

GlaxoSmithKline R\&D, Research Triangle Park

Durham, North Carolina, USA

e-mail: s.m.chandrashekhar@gsk.com causal inference between INFP and olfactory and gustatory dysfunction.

Keywords: Allergic rhinitis; Bradford Hill criteria; Causality assessment; Intranasal fluticasone; Nasal polyposis; Olfactory and gustatory dysfunction; Respiratory

\section{INTRODUCTION}

Causality assessment is one of the central functions in pharmacovigilance. While there is no single widely accepted approach to determine causality, the Bradford Hill criteria are generally regarded as a comprehensive method available for this purpose. The criteria are multidimensional in the sense that nine distinct aspects of causal inference for an observed association between a specific agent and a disease (or drug and adverse event) are assessed; namely these are strength of association, consistency, specificity, temporality, biological gradient, plausibility, coherence, experiment, and analogy. Originally described in January 1965 by Sir Austin Bradford Hill, a pioneering English epidemiologist, the eponymous criteria have been used in epidemiology for more than 50 years, and regarded as a model for assessing causality in pharmacovigilance [1-4]. 


\section{Integration of Human Smell and Taste Functions}

Although served by distinct receptors and firstorder neurons, smell and taste are intimately entwined at the cortical perceptual interfaces, which results in comprehensive and intense olfactory-gustatory integration $[5,6]$. For example, the so-called gestalt experience of food flavor is much more than the mere sum of smell and taste elements; the percept of umami-the fifth taste-is another example. Such near complete integration and indeed super-additive perception of the two senses has been attributed to the extensive anatomical connections of several brain areas with both the primary gustatory and olfactory cortex and enhanced coupling of the limbic and temporal lobes. Excellent reviews of this fascinating topic are available $[7,8]$.

Humans perceive odors via two distinct pathways: via nostrils (e.g., sniffing) and via mouth (drinking and eating) called orthonasal and retronasal olfaction, respectively. The former occurs during inspiration and the latter occurs during expiration $[9,10]$. Retronasal olfaction is essential for flavor perception and is frequently confused with taste. Apparently, the confusion is so deep rooted that some languages do not have distinct words for "smelling" and "tasting" [10]. Taste is served by four cranial nerves (trigeminal, facial, glossopharyngeal, and vagus), which may explain why isolated impairment of taste is uncommon and true loss of taste is very rare $[11,12]$.

It is well known that only about $5 \%$ of all patients visiting smell and taste clinics actually suffer from taste disorders while about $95 \%$ of the patients have smell disorders [11, 13]. Therefore, in clinical practice the recommended first step is to rule out smell impairment in all cases of self-reported taste impairments [14]. Of the five special senses only smell and taste have not evolved as full-fledged medical/clinical specializations; dedicated smell and taste clinics are quite rare even in the developed world [15].

As a result of these factors and because smell and taste alterations in most individual case safety reports (ICSRs) are self-reported, it is very difficult to separate the two and ascertain true taste problems; therefore, the two adverse events were regarded as a single entity for the purpose of this causality assessment.

\section{Mechanisms of Drug-Induced Smell and Taste Loss}

Hundreds of prescription-only and over the counter (OTC) medicines are associated with smell and taste dysfunction [16]. For the majority of drugs, specific mechanisms leading to the occurrence of smell and taste alterations remain unknown [17]. Proposed theoretical mechanisms include primary effects of the offending drugs and secondary or collateral effects. Agonistic or antagonistic actions of drugs, modulation of neuronal action potential, alteration of neurotransmitter function, and changes in interplay between neural networks in CNS-associated perception of sense of smell and taste are proposed primary mechanisms. Some drugs have secondary effects like drying up of mucus secretion, reducing access to chemosensory receptors, altered chemistry or ionic milieu of receptors (change in constituents of mucus or saliva). Bitter taste of the offending drugs is often the only mechanism widely known to be responsible.

\section{Intranasal Fluticasone Propionate}

Intranasal fluticasone propionate (INFP), first approved in 1990, is an established therapeutic option for treatment of allergic rhinitis. It is also approved for the treatment of nasal polyposis in some countries outside the USA. Like other intranasal corticosteroids, such as beclomethasone dipropionate, budesonide, flunisolide, mometasone furoate monohydrate, and triamcinolone acetonide, INFP is labeled for the adverse events of alterations or loss of sense of smell and taste; this is primarily based on spontaneous case reports received during post-approval clinical use.

On the basis of evidence from anecdotal reports and controlled clinical trials, the empirical use of corticosteroids (intranasal, oral, and injectable) has evolved to fill the current therapeutic void to some degree. This 
paradoxical body of evidence presents unique challenges to the causality assessment of olfactory and gustatory dysfunction associated with INFP. It is remarkable that currently there are no medicines-approved or in development-for the treatment of smell and taste disorders, notwithstanding their increasing prevalence, negative consequences on quality of life, and significant unmet medical need. Specifically, none of the corticosteroids are indicated for use in the treatment of smell and taste disorders.

To the best of the authors' knowledge, this is the first comprehensive causality assessment of the relationship between intranasal corticosteroids and smell and taste dysfunction. In this narrative review, the Bradford Hill criteria are applied to assess whether exposure to INFP is causally linked to olfactory and gustatory dysfunction. This review also aims to demonstrate challenges inherent to causal inference that have been eloquently alluded to by Sir Bradford Hill as "...in what circumstances can we pass from this observed association to a verdict of causation?" [1].

A review of case reports of "taste and smell alterations" reported to the GlaxoSmithKline global safety database from March 1990 to August 2017 was independently performed by the authors. The Medical Dictionary for Regulatory Activities (MedDRA) preferred terms (PT) included were ageusia, anosmia, dysgeusia, hypergeusia, hypogeusia, hyposmia, and parosmia. Evidence relevant to the Hill criteria in the context of drug-induced olfactory and gustatory dysfunction was obtained from peer-reviewed published literature (Fig. 1).

This article is based on previously conducted studies and does not contain any studies with human participants or animals performed by any of the authors.

\section{APPLICATION OF THE BRADFORD HILL CRITERIA}

\section{Strength of Association}

A measure of strength of association is the comparative frequency of occurrence of smell and taste dysfunction in the general population versus the patient population exposed to INFP.

From March 1990 (first approval of INFP) to August 2017, GlaxoSmithKline's Global Clinical Safety and Pharmacovigilance Department received 914 cumulative case reports of smell and taste problems associated with INFP (includes ageusia, anosmia, dysgeusia, hypergeusia, hypogeusia, hyposmia, and parosmia), during which the estimated cumulative exposure was 32.2 million patient years (prescriptions) and 46 million OTC units (based on Intercontinental Medical Statistics (IMS) data). During the same period, the FDA Adverse Event Reporting System (FAERS) database included 385 cases of taste and smell alterations. The number of duplicate cases in the two databases is not known.

Well-known limitations of case reports include poor quality of narratives, absent or incomplete information, absence of key details regarding dechallenge and rechallenge, and concurrent medications. Assuming the worstcase scenario of causality in all reported cases (regardless of poor quality/un-assessable narratives, presence of confounding factors-background disease, concurrent medications known to cause smell and taste alterations, and absence of details of dechallenge and rechallenge) and assuming the worst-case scenario that only 1 in 100 events is reported because of underreporting of adverse events $[18,19]$, the total extrapolated number of reported cases would be 129,900 (i.e., $[914+385] \times 100$ ). On this basis, the frequency of occurrence of smell and taste alterations is estimated to be approximately 1.66 in 1000 subjects $(0.166 \%)$, $[(129,900) \div(46+32.2$ million $)]$. In comparison, the frequency of smell and taste alterations in the general population is $6-12 \%$ for self-reported olfactory impairments [20-22] and $5.7-13.3 \%$ for self-reported gustatory impairments [23, 24].

Furthermore, it is well known that olfactory dysfunction is a hallmark symptom of allergic rhinitis with frequency ranging from 10\% to 88\% (mode range, 20-40\%) [25-27].

In the general population dysgeusia (altered sense of taste) is reported in up to $34 \%$ of patients with smell and taste disorders [11] but 


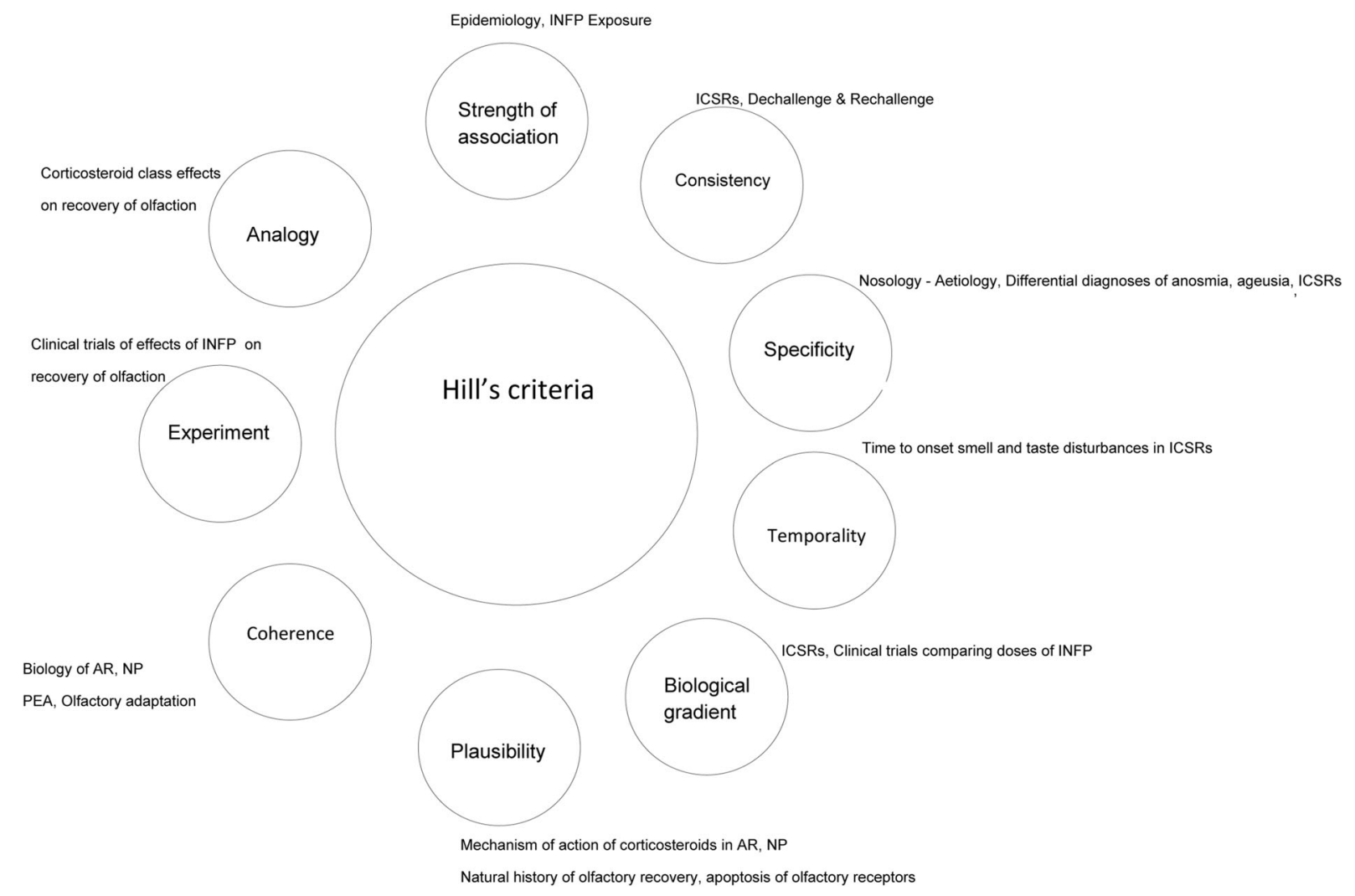

Fig. 1 Schematic representation of Hill's criteria for causality assessment and corresponding bodies of evidence or data. INFP intranasal fluticasone propionate, ICSR

true ageusia is very rare [28]. In one study of 240 patients with allergic rhinitis, objective assessments (olfactometry by Elsberg and Levy's method and electrogustometry) revealed that the incidence of smell and taste disorders in patients with allergic rhinitis is $21.4 \%$ and $31.2 \%$, respectively [29]. Unfortunately, there is a paucity of epidemiological studies of taste disorders in allergic rhinitis and nasal polyposis.

Evidence described above shows that the frequency of occurrence of olfactory and gustatory dysfunction on exposure to INFP is orders of magnitude lower than the corresponding frequencies in the general population and patients with allergic rhinitis; hence the likelihood of causality is not supported. As Hill noted, absence of strength of association per se does not rule out causality. individual case safety reports, $A R$ allergic rhinitis, $N P$ nasal polyposis, $P E A$ phenyl ethyl alcohol

\section{Consistency}

In Hill's original context of epidemiology, "consistency" addressed whether the association between agent and disease was observed regardless of place, time, and circumstance. In pharmacovigilance, it has been defined as reproducibility of the drug-event pair at two levels: positive dechallenge and positive rechallenge at the level of individual case safety report (ICSR) and at an aggregate level where patterns of related factors contributing to reproducibility are assessed. A higher consistency strengthens the likelihood of causal inference [30].

On the basis of a recent review of global safety databases, very few cases (approximately $1.0 \%)$ reported positive dechallenge and positive rechallenge. Owing to the very low number of cases with adequate details of rechallenge 
and dechallenge, no consistent pattern of factors contributing to reproducibility was observed. The review also found a significant number of cases that describe persistence of smell and/or taste problems regardless of discontinuation of INFP therapy.

As a result of confounding by pre-existing sinonasal diseases that contribute to high background prevalence of the adverse events of interest, it is difficult to delineate consistent patterns of association between INFP therapy and smell and taste problems. Fortuitously fluticasone propionate (FP) formulations are available for administration via inhaled and topical dermal routes. These non-intranasal formulations of FP provide an opportunity to circumvent this issue. Use of inhaled FP (metered dose inhalers, dry powder inhalers, and nebules) was very rarely associated with smell and taste problems and these cases were confounded by concurrent sinonasal diseases and concurrent medications. There were no reports of smell and taste problems associated with cutaneous formulations (cream and ointment) of FP. A search of the literature found no reports of smell and taste alterations linked to these formulations.

In clinical trials of FP dry powder administered via swallowing in the treatment of eosinophilic esophagitis, smell or taste dysfunctions were not reported [31-33]. Following maxillary sinus irrigation with FP mixed in large volumes of saline for treatment of acute and chronic rhinosinusitis, smell and taste problems have not been reported [34, 35]. As non-intranasal formulations of FP are devoid of smell and taste problems there is lack of consistency of association.

\section{Specificity}

This is a measure of reproducibility of the event in specific situations; the likelihood of causality would be stronger when the association is observed in a specific population or a specific geographic location and the disease or event has no other valid explanation.

In the context of pharmacovigilance, specificity is interpreted as the occurrence of a drug-event pair under precise and narrowly defined circumstances and patient subsets; rarity of occurrence of the event in the general population and patients unexposed to the drug would add heft to the likelihood of causation. In other words, specificity asks the question: to what degree is the event solely attributable to the given drug?

Smell and taste alterations have numerous diverse etiologies ranging from common cold to cancer chemotherapy; in addition, factors such as advancing age, gender, smoking, alcohol consumption, poor dental oral hygiene, educational and social standards are known to alter or reduce perception of smell and taste [36]. Chronic conditions such as renal or hepatic failure, HIV infection, cancer, complicated type 2 diabetes mellitus, Parkinson's disease, Alzheimer's disease, Bell's palsy, cognitive impairment, and multiple sclerosis are principal causes of olfactory and gustatory dysfunction [14].

One of the most common causes of anosmia is sinonasal diseases, an umbrella term for seasonal and perennial allergic rhinitis, chronic rhinosinusitis with or without nasal polyps, and upper respiratory tract infections $[37,38]$.

It is estimated that more than 200 commonly prescribed medicines are linked to olfactory and gustatory dysfunction $[39,40]$. In the context of sinonasal diseases many of the medications used concurrently are known to be linked to smell and taste alterations. For instance, intranasal zinc, an OTC medicine available for therapy of common cold, is frequently associated with smell and taste loss that is occasionally reported to be persistent. Macrolide antibiotics, used to treat upper respiratory tract infections that commonly occur in subjects with allergic rhinitis, are most frequently associated with olfactory and gustatory dysfunction [17].

Therefore, smell and taste dysfunction are essentially due to diverse etiology. In most cases, valid alternative explanations would be available and weaken the likelihood of causal inference. Finally, an analysis of the case reports provides no evidence of specific and reproducible patterns of relationship between smell and taste alterations and exposure to INFP. 


\section{Temporality}

In the context of causal inference, temporality has the distinction of being the only sine qua non criterion. Hill observed that causality cannot be assumed if the adverse event occurs prior to drug exposure.

A recent systematic review of olfaction in allergic rhinitis found that frequency of olfactory dysfunction ranged widely from $10 \%$ to $88 \%$ of patients, with most studies reporting frequencies in the range of $20-40 \%$ [27]. Characteristically, olfactory dysfunction fluctuates over time on the basis of severity of allergic rhinitis and related sinonasal diseases. Patients tend to exhibit a continuum of olfactory loss ranging from mild to progressively severe across the spectrum of allergic rhinitis, nasal polyposis, chronic rhinosinusitis, and upper respiratory tract infections [41]. Upper respiratory tract infections due to viral etiology frequently complicate allergic rhinitis via inflammatory damage to olfactory epithelium, which in turn aggravates fluctuations of olfactory performance and loss [38]. Fluctuations may also be physiological because of the cyclical apoptosis and regeneration of receptors throughout life; human olfactory receptor cells and gustatory receptor cells have a life-span of about 30-60 days and 10 days, respectively [12]. Hence in most subjects with allergic rhinitis and nasal polyposis the likelihood of presence of smell and taste dysfunction prior to exposure to INFP cannot be ruled out.

Time to onset of smell and taste alterations associated with use of INFP in most case reports was poorly documented. In 313 cases the time to onset was reported and ranged from immediate to 20 years; no consistent pattern of onset was observed.

\section{Biological Gradient (Dose-Response Curve)}

When the degree of response (event) is commensurate with the magnitude of exposure to an agent (offending drug), a positive dose response is said to support an observed association, and such evidence is of considerable importance as it would strengthen causal inference. The majority of case narratives did not provide details of dose, frequency, or both. In the few reports that provided details of dosing, INFP dose varied from one spray per nostril once daily to two sprays per nostril twice daily. Case safety reports did not provide adequate data to support or refute a relationship between dose of INFP and degree of smell and taste alterations. Also, a search of the literature did not find studies addressing this question.

Paradoxically there is some evidence of dose response from anecdotal reports and clinical trials that show clinically significant beneficial effects of INFP on olfactory and gustatory performance. These data tend to support a positive dose-response curve (see Table 1). In terms of olfactory improvement, fluticasone propionate nasal drops (FPND) $400 \mathrm{mcg}$ bid was the most effective, followed by FPND $400 \mathrm{mcg}$ od and fluticasone propionate aqueous nasal spray (FPANS) $200 \mathrm{mcg}$ bid while FPANS $200 \mathrm{mcg}$ od was moderately effective [42-44] (see "Experiment" for details). However, the dose-response curve and optimal dose of INFP or other corticosteroids in improving smell and taste performance have not been established.

\section{Plausibility}

Plausibility is when credible and logical explanations are available to support an observed association. Biological and mechanistic plausibility is an important element of causal inference. In the context of pharmacovigilance, plausibility focuses on the mechanism of action and effects of the medicine in relation to the adverse event.

Like other corticosteroids, FP has potent anti-inflammatory effects. It acts at the intracellular glucocorticoid receptor level via modification of transcription; the resulting range of cellular consequences are described as downregulation of pro-inflammatory molecules and cells (Langerhans cells, lymphocytes, mast cells, eosinophils, and basophils) and upregulation of anti-inflammatory molecules. In the context of intranasal corticosteroids, it is not known whether nasal mucosal penetration per se is 
Table 1 Improvements in olfactory and gustatory performance reported in clinical trials of patients with allergic rhinitis or nasal polyposis treated with intranasal fluticasone propionate

\begin{tabular}{|c|c|c|c|c|}
\hline Study & Key details & Endpoint & Outcome & Comments \\
\hline $\begin{array}{l}\text { Klimek et al. } \\
{[68]}\end{array}$ & $\begin{array}{l}\text { Prospective observational } \\
\text { study } \\
\text { Allergic rhinitis patients } \\
\text { mild }(n=6), \text { moderate } \\
(n=27) \text {, and severe } \\
(n=14) \text {. Intranasal } \\
\text { azelastine } 548 \\
\text { mcg + INFP200 mcg } \\
\text { combination spray } \\
\text { Treatment duration } \\
3 \text { months }\end{array}$ & $\begin{array}{l}\text { Anosmia in } \\
\text { allergic rhinitis } \\
\text { Recovery } \\
\text { measured by } \\
\text { TDI (threshold, } \\
\text { determination, } \\
\text { and } \\
\text { identification) } \\
\text { score }\end{array}$ & $\begin{array}{l}\text { Significant improvement } \\
\text { in olfactory function } \\
\text { with restoration of } \\
\text { normosmia in } 44 / 47 \\
(94 \%) \text { at } 1 \text { month and } \\
\text { in all } 47 \text { patients at } \\
3 \text { months }\end{array}$ & $\begin{array}{l}\text { First study to show } \\
\text { normosmia was achieved } \\
\text { in all patients; azelastine } \\
\text { reportedly has bitter } \\
\text { taste. Unfortunately, } \\
\text { effect on taste function } \\
\text { was not assessed }\end{array}$ \\
\hline Ye [67] & $\begin{array}{l}\text { Non-randomized clinical } \\
\text { trial. Patients }(n=55) \\
\text { with chronic } \\
\text { rhinosinusitis with nasal } \\
\text { polyps } \\
\text { FPANS } 400 \text { mcg bid for } \\
3 \text { months after FESS } \\
\text { Follow-up } 1 \text { year }\end{array}$ & $\begin{array}{l}\text { Subjective } \\
\text { improvement } \\
\text { in olfaction }\end{array}$ & $\begin{array}{l}\text { Significant improvement } \\
\text { in olfaction in most } \\
\text { patients }\end{array}$ & $\begin{array}{l}\text { Significant correlation } \\
\text { between olfactory scores } \\
\text { and eosinophil counts at } \\
1 \text { year }\end{array}$ \\
\hline $\begin{array}{c}\text { Vaidyanathan } \\
\text { et al. }[43]\end{array}$ & $\begin{array}{l}\text { Controlled clinical trial } \\
\text { nasal polyposis }(n=60) \\
\text { Period 1: oral prednisolone } \\
25 \mathrm{mg} \text { /days or placebo for } \\
2 \text { weeks } \\
\text { Period } 2 \text { both groups: } \\
\text { FPND } 400 \mathrm{mcg} \text { bid, for } \\
8 \text { weeks and then FPANS } \\
200 \text { mcg bid for } 18 \text { weeks }\end{array}$ & $\begin{array}{l}\text { Polyp size, nasal } \\
\text { symptoms, } \\
\text { hyposmia score }\end{array}$ & $\begin{array}{l}\text { Initial prednisolone } \\
\text { therapy followed by } \\
\text { topical FP is more } \\
\text { effective than topical } \\
\text { FP alone in reducing polyp } \\
\text { size and improving } \\
\text { olfaction }\end{array}$ & $\begin{array}{l}\text { FPND and FPANS } \\
\text { sustained improvement } \\
\text { of hyposmia over } \\
28 \text { weeks }\end{array}$ \\
\hline $\begin{array}{l}\text { Olsson et al. } \\
{[66]}\end{array}$ & $\begin{array}{l}\text { Nasal polyps with asthma } \\
\text { post FESS } \\
\text { FPND } 400 \mathrm{mcg} \text { bid or } \\
\text { placebo } \\
\text { Treatment duration } \\
14 \text { weeks }(n=68)\end{array}$ & $\begin{array}{l}\text { QoL SF-36 } \\
\text { Sense of smell } \\
\text { assessed }\end{array}$ & $\begin{array}{l}\text { FPND arm significant } \\
\text { improvement in sense of } \\
\text { smell and } 3 \text { other SF-36 } \\
\text { domains }\end{array}$ & $\begin{array}{l}\text { Study showed FPND } \\
\text { improves sense of smell } \\
\text { as well as QoL }\end{array}$ \\
\hline
\end{tabular}


Table 1 continued

\begin{tabular}{|c|c|c|c|c|}
\hline Study & Key details & Endpoint & Outcome & Comments \\
\hline $\begin{array}{l}\text { Jankowski } \\
\text { et al. [42] }\end{array}$ & $\begin{array}{l}\text { Nasal polyposis } \\
3 \text { periods: acute, } \\
\text { maintenance, and follow- } \\
\text { up; duration in months } 1 \text {, } \\
\text { 1, and 6, respectively } \\
\text { Group } 1 \text { FPANS } 400 \text { mcg } \\
\text { bid in all } 3 \text { periods } \\
(n=79 \text { ). Group } 2 \\
\text { FPANS spray } 400 \text { mcg } \\
\text { bid in period } 1 ; 200 \mathrm{mcg} \\
\text { od during periods } 2 \text { and } 3 \\
(n=82 \text { ). Group } 3 \\
\text { placebo during periods } 1 \\
\text { and } 2 \text {, FPANS } 200 \text { mcg } \\
\text { bid in period } 3 \text { ( } n=81 \text { ). } \\
\text { Treatment duration } \\
8 \text { months }\end{array}$ & $\begin{array}{l}\text { Peak nasal } \\
\text { inspiratory flow } \\
\text { rate (PNIF); } \\
\text { symptom scores }\end{array}$ & $\begin{array}{l}\text { PNIF and symptom scores } \\
\text { improved; } 200 \mathrm{mcg} \text { bid } \\
\text { was more effective at all } \\
\text { end points. Sense of } \\
\text { smell and sense of taste } \\
\text { improved significantly }\end{array}$ & $\begin{array}{l}\text { The only study to report } \\
\text { improved smell and taste } \\
\text { (significant at } 1 \text { month } \\
p<0.001 \text { and } p<0.05 \\
\text { for smell and taste, } \\
\text { respectively) }\end{array}$ \\
\hline $\begin{array}{l}\text { Vlckova et al. } \\
{[65]}\end{array}$ & $\begin{array}{l}\text { Nasal polyposis FPANS } \\
\quad 400 \text { mcg bid or placebo } \\
\text { Treatment duration } \\
12 \text { weeks ( } n=109 \\
\text { recruited, } 106 \text { completed) }\end{array}$ & $\begin{array}{l}\text { Nasal symptoms } \\
\text { including } \\
\text { anosmia }\end{array}$ & $\begin{array}{l}\text { Significantly reduced } \\
\text { polyp size; significant } \\
\text { sustained reduction in } \\
\text { nasal symptoms and } \\
\text { anosmia at weeks } 4,8 \text {, } \\
\text { and } 12\end{array}$ & $\begin{array}{l}\text { FPANS was administered } \\
\text { via breath actuated } \\
\text { device }\end{array}$ \\
\hline $\begin{array}{l}\text { Demirel et al. } \\
\text { [64] }\end{array}$ & $\begin{array}{l}\text { Nasal polyposis } \\
\text { FPANS } 100 \mathrm{mcg} \text { bid } \\
\text { FPND } 400 \mathrm{mcg} \text { od } \\
\text { FPND } 400 \mathrm{mcg} \text { bid } \\
\text { Treatment duration } \\
12 \text { weeks }(n=34)\end{array}$ & $\begin{array}{l}\text { Polyp size } \\
\text { reduction } \\
\text { Nasal symptoms } \\
\text { including } \\
\text { anosmia }\end{array}$ & $\begin{array}{l}\text { Significant reduction } \\
\text { polyp size at } 4,8 \text {, and } \\
12 \text { weeks with twice } \\
\text { daily dose } \\
\text { Significant recovery of } \\
\text { olfaction only with } \\
\text { FPND } 400 \text { mcg bid dose }\end{array}$ & $\begin{array}{l}\text { Shows dose response of } \\
\text { INFP }\end{array}$ \\
\hline $\begin{array}{l}\text { Rowe-Jones } \\
\text { et al. [63] }\end{array}$ & $\begin{array}{l}\text { Nasal polyposis post FESS } \\
\text { FPANS } 200 \text { mcg bid } \\
\quad(n=55) \\
\text { Placebo }(n=54) \\
\text { Treatment duration } 5 \text { years } \\
(n=109,77 \text { with nasal } \\
\text { polyps, } 72 \text { completed } \\
5 \text { years })\end{array}$ & $\begin{array}{l}\text { Nasal symptoms } \\
\text { improvement }\end{array}$ & $\begin{array}{l}\text { Olfaction significantly } \\
\text { improved in FPANS } \\
\text { arm at } 1 \text { and } 2 \text { years } \\
\text { post operation }\end{array}$ & $\begin{array}{l}\text { Longest duration study to } \\
\text { date. FPANS group } \\
\text { required significantly less } \\
\text { rescue medication and } \\
\text { had significantly less } \\
\text { polyp recurrence over } \\
5 \text { years }\end{array}$ \\
\hline
\end{tabular}


Table 1 continued

\begin{tabular}{|c|c|c|c|c|}
\hline Study & Key details & Endpoint & Outcome & Comments \\
\hline $\begin{array}{l}\text { Aukema et al. } \\
\text { [62] }\end{array}$ & $\begin{array}{l}\text { Nasal polyps awaiting } \\
\text { surgery } \\
\text { FPND }(n=27) \\
\text { Placebo }(n=27) \\
\text { Treatment duration } \\
12 \text { weeks }\end{array}$ & $\begin{array}{l}\text { Need for surgery } \\
\text { Nasal symptoms } \\
\text { including } \\
\text { anosmia }\end{array}$ & $\begin{array}{l}\text { FPND eliminated need for } \\
\text { surgery in } 13 \text { of } 27 \text { vs. } 6 \\
\text { of } 27 \text { in placebo group } \\
\text { FPND group achieved } \\
\text { significant reduction in } \\
\text { loss of smell }(p=0.004)\end{array}$ & $\begin{array}{l}\text { All patients had received } \\
\text { intranasal corticosteroid } \\
\text { spray for } 3 \text { months } \\
\text { (with no satisfactory } \\
\text { result) before entry. } \\
\text { Majority of patients in } \\
\text { both groups had } \\
\text { previous sinus surgeries } \\
\text { for polyps }\end{array}$ \\
\hline $\begin{array}{l}\text { Dijkstra et al. } \\
{[60]}\end{array}$ & $\begin{array}{l}\text { Nasal polyps awaiting FESS } \\
\text { INFP } 400 \mathrm{mcg} \text { bid } \\
\text { INFP } 800 \mathrm{mcg} \text { bid } \\
\text { Placebo } \\
\text { Treatment duration } 1 \text { year } \\
\text { ( } n=162 \text { recruited, } 59 \\
\text { completed) }\end{array}$ & $\begin{array}{l}\text { Nasal symptoms } \\
\text { including } \\
\text { anosmia }\end{array}$ & $\begin{array}{l}\text { No difference in any } \\
\text { outcome between the } \\
\text { three groups }\end{array}$ & $\begin{array}{l}\text { Patients were non- } \\
\text { responders to } \\
\text { corticosteroids }\end{array}$ \\
\hline $\begin{array}{l}\text { Blomqvist } \\
\text { et al. [61] }\end{array}$ & $\begin{array}{l}\text { Anosmia } \\
\text { Pre-trial open phase } \\
\text { ( } n=40 \text { anosmia } \\
\text { patients): 10-day therapy } \\
\text { with oral prednisolone } \\
40 \text { mg od for } 3 \text { days, } \\
\text { tapering by } 5 \text { mg/day. } \\
\text { Concurrent FPANS } 200 \\
\text { mcg per day. Those } \\
\text { with } \geq 2 \text { step } \\
\text { improvement in butanol } \\
\text { odor test entered blinded } \\
\text { phase } \\
\text { Blinded phase: } \\
\text { FPANS }(n=20) \text {, placebo } \\
(n=10) \text {, controls } \\
(n=10) \text { Treatment } \\
\text { duration } 6 \text { months }\end{array}$ & $\begin{array}{c}\text { Effect of FPANS } \\
\text { on olfaction } \\
\text { during long- } \\
\text { term therapy }\end{array}$ & $\begin{array}{l}\text { Significant improvement } \\
\text { in sense of smell after } \\
\text { the 10-day open phase; } \\
\text { during blinded phase the } \\
\text { olfactory improvement } \\
\text { remained at the same } \\
\text { level in placebo and } \\
\text { FPANS groups but } \\
\text { deteriorated sharply in } \\
\text { the control group }\end{array}$ & $\begin{array}{l}\text { 23/40 patients had upper } \\
\text { respiratory tract } \\
\text { infection; treatment } \\
\text { with local } \\
\text { corticosteroids does not } \\
\text { restore olfactory } \\
\text { function in those with } \\
\text { damage to olfactory } \\
\text { epithelium }\end{array}$ \\
\hline
\end{tabular}


Table 1 continued

\begin{tabular}{|c|c|c|c|c|}
\hline Study & Key details & Endpoint & Outcome & Comments \\
\hline $\begin{array}{l}\text { Penttilä et al. } \\
\text { [44] }\end{array}$ & $\begin{array}{l}2 \text { weeks run in } \\
\text { FPND } 400 \text { mcg od } \\
(n=48) \text {, FPND } 400 \mathrm{mcg} \\
\text { bid }(n=47) \text {, placebo } \\
(n=47) \text {. Treatment } \\
\text { duration } 12 \text { weeks, post } \\
\text { treatment } 12 \text { weeks in } \\
\text { open phase }\end{array}$ & $\begin{array}{l}\text { Polyp size } \\
\text { Nasal symptoms } \\
\text { including } \\
\text { olfaction }\end{array}$ & $\begin{array}{l}\text { At week } 12 \text { polyp size } \\
\text { reduction achieved in } \\
\text { FPND groups ( } 24 \% \text { and } \\
41 \%) \\
\text { Significant improvement } \\
\text { in olfactory function }\end{array}$ & $\begin{array}{l}\text { Higher dose of FPND } \\
\text { may have resulted in } \\
\text { significant effect on } \\
\text { olfactory recovery }\end{array}$ \\
\hline $\begin{array}{l}\text { Lund et al. } \\
\text { [58] }\end{array}$ & $\begin{array}{l}\text { Severe polyposis. } \\
\text { FPANS }(n=10), \\
\text { beclomethasone } \\
\text { dipropionate aqueous } \\
\text { nasal spray }(n=10), \\
\text { placebo }(n=9) \\
12 \text { weeks of treatment, } \\
2 \text { weeks of follow-up }\end{array}$ & $\begin{array}{l}\text { Need for } \\
\text { polypectomy } \\
\text { Nasal symptoms } \\
\text { including } \\
\text { anosmia }\end{array}$ & $\begin{array}{l}\text { No significant difference } \\
\text { in polyp size; no effect } \\
\text { on sense of smell }\end{array}$ & $\begin{array}{l}\text { Study enrolled subjects } \\
\text { with very severe } \\
\text { polyposis } \\
\text { While there was no effect } \\
\text { on anosmia, rhinitis } \\
\text { decreased significantly }\end{array}$ \\
\hline $\begin{array}{l}\text { Keith et al. } \\
\text { [59] }\end{array}$ & $\begin{array}{l}\text { Nasal polyps } \\
\text { FPND }(n=52) \text {, placebo } \\
(n=52), 12 \text { weeks of } \\
\text { treatment. } 12 \text { weeks open } \\
\text { extension (all received } \\
\text { FPANS) }\end{array}$ & $\begin{array}{l}\text { Need for } \\
\text { polypectomy } \\
\text { Nasal symptoms } \\
\text { including } \\
\text { anosmia }\end{array}$ & $\begin{array}{l}\text { Polyp size reduction } 27 \% \\
\text { vs. } 16 \% \\
\text { Nasal blockage cleared } \\
55 \% \text { vs. } 22 \% \\
\text { No significant difference } \\
\text { of effects on olfactory } \\
\text { function }\end{array}$ & $\begin{array}{l}\text { FPNS has low systemic } \\
\text { bioavailability }(0.6 \% \text { vs. } \\
\text { that of FPANS }(0.51 \%)\end{array}$ \\
\hline
\end{tabular}

FESS functional endoscopic sinus surgery, INFP intranasal fluticasone propionate, FPND fluticasone propionate nasal drops, FPANS fluticasone propionate aqueous nasal spray, PNIF peak nasal inspiratory flow rate, TDI score threshold, determination, and identification score

sufficient or the penetration beneath the mucous membrane and access to systemic circulation is necessary for the medicine to exert its clinical effects. However, because of the very low systemic exposure of INFP at clinically achieved doses, clinical benefit is thought to be primarily due to nasal mucosal actions [45].

Eosinophil-mediated inflammation is characteristic of allergic rhinitis and nasal polyposis $[45,46]$. Correlation between sinus mucosal eosinophil counts and clinical olfactory impairment has been shown in allergic rhinitis and nasal polyposis [47, 48]. INFP therapy in allergic rhinitis reduces eosinophils on the mucosal surface, epithelium, lamina propria, and blood after allergen challenge. Also, INFP therapy appears to reduce the degranulation propensity of eosinophils in the nose and in the circulation [49, 50]. Importantly, concentration-dependent induction of apoptosis of human eosinophils on exposure to clinically achieved concentrations of FP has been 
demonstrated [51]. Similar studies on taste disturbances are not available. Alterations or loss of sense of smell and taste cannot be explained by the established knowledge of the mechanism of action and clinical effects of corticosteroids. Evidence of biologic or mechanistic plausibility that smell and taste disturbances are attributable to INFP is lacking.

INFP has been shown to reduce intranasal inflammation, restore patency of nasal passages, and reduce mucosal congestion leading to reduced mucus secretion in subjects with allergic rhinitis. These effects in turn restore airway access to the 6 million olfactory neurons housed in an area approximately $2 \mathrm{~cm}^{2}$ at the roof of the nasal cavity (olfactory cleft) leading to re-establishment of entry of odor chemicals that are essential for chemosensory transmission and odor perception. In nasal polyposis, INFP has been shown to produce the classic anti-inflammatory effects detailed above and reduce polyp size, reduces vascularity of the polyps, and restores access to the osteomeatal complex during surgical removal of polyps, with reduced risk of perioperative bleeding. Overall these effects would help improve olfaction. The known mechanism of action and antiinflammatory effects of corticosteroids provide adequate explanation for the observed beneficial effects of INFP on olfactory dysfunction and collateral improvement in gustation.

It should be noted that complete or adequate recovery of smell and taste dysfunction occurs in more than two-thirds of patients over the long term (2-3 years) after cessation of the causative exposure $[52,53]$. Therefore, spontaneous recovery is likely to confound and lead to the post hoc ergo propter hoc fallacy. No studies to date have addressed this question.

\section{Coherence}

Coherence asks whether interpretation of an observed association is compatible with the known natural history, biology, and general understanding of the disease. While plausibility aims to explore and identify mechanistic hypotheses to support causal inference, coherence seeks to ensure if such inference is credible and aligned to the current knowledge.

The question is whether determination of causality between INFP treatment and dysfunction of smell and taste would be aligned with the current understanding of allergic rhinitis, nasal polyps, and smell and taste disorders. Such determination would indeed conflict with what is currently known about allergic rhinitis, nasal polyps, and smell and taste disorders. As described above (see "Plausibility"), the current understanding of allergic rhinitis, nasal polyposis as well as the mechanism of action and clinical benefits of INFP on smell and taste disturbances together present a coherent body of knowledge.

Hill observed that the coherence would change over time because of newer findings and advances. Accordingly, recent findings in this context were reviewed. INFP contains phenyl ethyl alcohol (PEA), an excipient that serves as an antimicrobial preservative and imparts a pleasant floral scent. During regular use of INFP, the repeated exposure to PEA may contribute to olfactory impairment due to olfactory adaptation (reduced perception of smell upon repeated or continuous exposure), which is a well-known phenomenon; volunteer studies have shown that olfactory adaptation occurs during PEA exposure [54]. However, adaptation studies in patients with allergic rhinitis or nasal polyposis are not available. Intriguingly, PEA is also used as an additive in cigarettes, and smoking is a known risk factor for significant olfactory dysfunction [55]. A recent study of odor perception in smokers demonstrated significant and extended impairment of odor perception and the degree of impairment correlated with duration of smoking; the findings remained significant after adjusting for confounding due to PEA in the cigarettes [56]. It is hypothesized that smoking induces olfactory neuronal apoptosis leading to disruption of olfactory epithelium [56]. One large study $(n=1144$ subjects $)$ showed that at least $20 \%$ of patients with allergic rhinitis were active smokers [57].

The clinical significance of PEA exposure and olfactory adaptation (desensitization and recovery) in the context of allergic rhinitis, nasal polyposis, and corticosteroid exposure is 
unknown. The effects of repeated exposure to PEA via medication or smoking may contribute to olfactory and gustatory dysfunction but are not fully understood; further studies are required.

None of the putative mechanisms of druginduced dysfunction of smell and taste (see "Introduction") have been shown to be relevant to the known pharmacological actions and effects of INFP. Furthermore, literature search did not find insights or proposed mechanisms specific to smell and taste disturbances associated with INFP.

\section{Experiment}

Hill noted that well-designed experiments may provide strong evidence to support causality. Given the nascent birth of clinical trials circa 1965 when he introduced the criteria, experiment as originally defined did not specifically refer to clinical trials. In the context of pharmacovigilance, experiments have been interpreted to include anecdotal reports, clinical trials, and animal experiments, although the clinical significance of the last of these is largely unknown as extrapolation to humans is challenging.

\section{Clinical Trials}

A search of literature and clinical trial databases did not find studies that reported smell and taste dysfunction due to treatment with INFP.

On the contrary, INFP has been shown to improve olfaction in allergic rhinitis and nasal polyps in randomized controlled clinical trials, and one trial reported improved sense of taste as well [42]. The trials used different study designs, methods, and sample sizes. Three trials did not find significant effects on olfaction [58-60]; 11 studies [42-44, 61-68] that totaled 866 patients treated with INFP from 3 months to 5 years showed significant improvements in olfaction (see Table 1 for summary of the studies).

A prospective observational study in patients with mild, moderate, or severe perennial allergic rhinitis (PAR) treated with intranasal azelastine $548 \mathrm{mcg}+$ INFP $200 \mathrm{mcg}$ once daily reported significant beneficial effects on anosmia and nasal symptoms; $93-96 \%$ patients achieved complete recovery of normal sense of smell at 1 month of therapy with further complete recovery of olfaction achieved in $100 \%$ of patients at 3 months of therapy [68]. This was the first and only study to report full recovery of olfaction in all participants. It may be noted that azelastine is reported to have an especially bitter taste and the combination product is labeled for "disturbances or loss of smell and taste". Unfortunately, effects on taste were not assessed in this trial; however, the findings suggest that INFP may contribute to complete restoration of the sense of smell. Given the limitations of this study, further trials are required. Other clinical trials show that INFP significantly improves olfactory dysfunction. However, there is a paucity of clinical trials that address the effects of INFP on taste dysfunction.

\section{Other Experiments}

In 22 patients with nasal polyposis the effects of FPANS $200 \mathrm{mcg}$ per day for 2 weeks on the induction of apoptosis of infiltrating inflammatory cells in explants from post-treatment biopsies was assessed. Explants of polyps were also exposed to dexamethasone to assess effects on apoptosis. While FPANS showed little effect on apoptosis, dexamethasone induced significant apoptosis [69]. The clinical significance of these findings is not known. In contrast, Zhang et al. compared induction of apoptosis of human eosinophils after exposure to FP, budesonide, beclomethasone, and dexamethasone. Fluticasone propionate produced twofold increase in eosinophil apoptosis compared to controls at clinically achievable drug concentrations, was equipotent to budesonide but significantly more potent than beclomethasone and dexamethasone [51]. As discussed previously reduced eosinophil count correlates with improvement in olfactory performance.

A literature search found no clinical or experimental evidence to suggest causal link between smell and taste dysfunction and exposure to INFP. 


\section{Analogy}

In the context of pharmacovigilance, analogy is interpreted as similar evidence from another drug in the same class. Corticosteroids are one of the largest class of medicines. Oral and injectable administration of different doses has shown clinically beneficial and occasionally dramatic improvements in patients with longstanding smell loss. Clinical trials of other intranasal corticosteroids (budesonide and mometasone) have shown clinical benefits on olfactory disturbances in patients with nasal polyposis [70-79]. In a pilot study of patients with seasonal allergic rhinitis (SAR), treatment with intranasal mometasone furoate for 2 weeks was associated with significant reduction in inflammation of olfactory cleft mucosa, reduction of eosinophils in olfactory epithelium, and improvement in olfactory quality of life [80]. This study showed that inflammation in SAR can affect the olfactory cleft and suggests direct role for allergic inflammation in smell loss.

Empirical oral or parenteral administration of large doses of corticosteroids is reported to result in recovery of olfaction. A single dose of $17.1 \mathrm{mg}$ betamethasone administered via epidural injection for acute back pain in a 42-year-old man with previous history of complete loss of smell 15 years prior was reported to result in dramatic complete recovery of sense of smell within $24 \mathrm{~h}$ of the injection. This report was aptly titled "The sweet smell of success" [81]. Anecdotal use of oral prednisolone $40 \mathrm{mg}$ per day for 4 weeks resulted in adequate recovery of taste in a patient with trigeminal neuropathy due to systemic sclerosis [82]. Orally or parenterally administered prednisolone is known to improve olfaction in some patients with anosmia due to traumatic and sinonasal disease [83-86].

\section{LIMITATIONS}

This causality assessment has a number of limitations. First, patients are unable to distinguish between smell and taste disturbances in general. Second, in patients with allergic rhinitis and nasal polyps there is high background prevalence of smell and taste disturbances. Third, concurrent medications (e.g., antibiotics, intranasal zinc) used in the treatment of upper respiratory tract infections, which commonly complicate allergic rhinitis and nasal polyps, are known to be associated with smell and taste disturbances. As a result of these factors smell and taste alterations are inextricable and were considered as a single entity for the purpose of this causality assessment. Fourth, as a result of anatomical, physiological, and perceptual overlaps in perception of smell and taste, the potential improvement in olfaction due to INFP may result in secondary improvement in taste but there is lack of studies that have addressed this question. Fifth, the total number of ICSRs with smell and taste alterations was 914, which represents significant underreporting. Sixth, the quality of the narratives of the majority of ICSRs was inadequate to support meaningful analysis, interpretation, and extrapolation. Finally, literature, known pharmacology, and nosology provide adequate information to assess eight Hill's criteria, namely strength of association, consistency, specificity, temporality, plausibility, coherence, experiment, and analogy; however, the evidence to assess biological gradient is rather limited.

\section{CONCLUSION}

Randomized controlled clinical trials comparing patients with allergic rhinitis treated with INCS or topical antihistamines to healthy subjects treated with INCS may provide conclusive evidence.

In this review the strength of the association between exposure to INFP and olfactory and gustatory dysfunction was found to be weak because of the preponderance of these events in the general population and patients with allergic rhinitis and nasal polyps compared with those exposed to INFP. No patterns of consistency and specificity of the drug-event pairs were observed. Presence of smell and taste dysfunction prior to therapy with INFP in cases of allergic rhinitis and nasal polyposis cannot be ruled out and therefore temporality cannot be established. There is no evidence to support a positive 
dose-response relationship (biologic gradient) between exposure to INFP and the degree of olfactory and gustatory impairment. On the basis of the known biology and natural history of allergic rhinitis and nasal polyposis and the mechanism of action and effects of INFP, there is lack of plausibility. As the notion of causal link between exposure to INFP and olfactory and gustatory dysfunction would fundamentally conflict with the current understanding of allergic rhinitis and nasal polyposis, coherence is conspicuous by absence. Randomized controlled trials (experiment) show consistent clinical benefits of INFP and other intranasal corticosteroids in patients with smell and taste disorders. Corticosteroids administered via oral or injectable routes are known to provide beneficial effects on smell and taste disorders (analogy). In summary, application of Hill's criteria finds that INFP treatment is not causally linked to smell and taste disturbances.

Perhaps Sir Bradford Hill would agree that on the basis of evidence for this observed association the verdict of causation shall not pass.

\section{ACKNOWLEDGEMENTS}

Trademark MedDRA ${ }^{\circledR}$ is owned by International Federation of Pharmaceutical Manufacturers and Associations on behalf of ICH. Prescription and OTC exposure data is provided by IMS Health (Now renamed IQVIA).

Funding. The authors carried out this work as part of their employment with GSK. No sources of funding were used to conduct this study or prepare the manuscript. Article processing charges and open access fee were funded by GSK.

Authorship. All named authors meet the International Committee of Medical Journal Editors (ICMJE) criteria for authorship for this article, take responsibility for the integrity of the complete work, and have given their approval for this version to be published. All authors had full access to all of the data in this study and take complete responsibility for the integrity of the data and accuracy of the data analysis.

Disclosures. Chandrashekhar S. Muganurmath is an employee and stockholder at GSK. Amy L. Curry is an employee and stockholder at GSK. Andrew H. Schindzielorz is an employee and stockholder at GSK. There are no other conflicts of interest relevant to the contents of the article.

Compliance with Ethics Guidelines. This article is based on previously conducted studies and does not contain any studies with human participants or animals performed by any of the authors.

Data Availability. Data sharing is not applicable to this article as no datasets were generated or analyzed during the current study.

Open Access. This article is distributed under the terms of the Creative Commons Attribution-NonCommercial 4.0 International License (http://creativecommons.org/licenses/ by-nc/4.0/), which permits any noncommercial use, distribution, and reproduction in any medium, provided you give appropriate credit to the original author(s) and the source, provide a link to the Creative Commons license, and indicate if changes were made.

\section{REFERENCES}

1. Hill $\mathrm{AB}$. The environment and disease: association or causation? Proc R Soc Med. 1965;58:295-300.

2. Perrio M, Voss S, Shakir SA. Application of the Bradford Hill criteria to assess the causality of cisapride induced arrhythmia: a model for assessing causal association in pharmacovigilance. Drug Saf. 2007;30(4):333-46.

3. Davidson TM, Smith WM. The Bradford Hill criteria and zinc-induced anosmia: a causality analysis. Arch Otolaryngol Head Neck Surg. 2010;136(7):673-6.

4. Anderson N, Borlak J. Correlation versus causation? Pharmacovigilance of the analgesic flupirtine exemplifies the need for refined spontaneous ADR 
reporting. PLoS One. 2011;6(10):e25221. https:// doi.org/10.1371/journal.pone.0025221.

5. Small DM, Voss J, Mak YE, Simmons KB, Parrish T, Gitelman D. Experience-dependent neural integration of taste and smell in the human brain. J Neurophysiol. 2004;92(3):1892-903.

6. Lundstrom JN, Boesveldt S, Albrecht J. Central processing of the chemical senses: an overview. ACS Chem Neurosci. 2011;2:5-16.

7. Seubert J, Ohla K, Yokomukai Y, Kellermann T, Lundström JN. Superadditive opercular activation to food flavor is mediated by enhanced temporal and limbic coupling. Hum Brain Mapp. 2015;36(5):1662-76.

8. Small DM, Prescott J. Odor/taste integration and the perception of flavor. Exp Brain Res. 2005;166(3-4):345-57.

9. Masaoka Y, Satoh H, Akai L, Homma I. Expiration: the moment we experience retronasal olfaction in flavor. Neurosci Lett. 2010;473(2):92-6.

10. Bojanowski V, Hummel T. Retronasal perception of odors. Physiol Behav. 2012;107(4):484-7.

11. Hummel T, Landis BN, Hüttenbrink KB. Smell and taste disorders. GMS Curr Top Otorhinolaryngol Head Neck Surg. 2011;10:Doc04.

12. DeVere R. Disorders of taste and smell (2, Selected Topics in Outpatient Neurology). Continuum (Minneap Minn). 2017;23:421-46.

13. Deems DA, Doty RL, Settle RG, et al. Smell and taste disorders: a study of 750 patients from the University of Pennsylvania Smell and Taste Center. Arch Otorhinolaryngol Head Neck Surg. 1991;117:519-28.

14. Malaty J, Malaty IA. Smell and taste disorders in primary care. Am Fam Phys. 2013;88(12):852-9.

15. Philpott C. Smell and taste disorders in the UK: first experiences with a specialized smell and taste outpatient clinic. Ann R Coll Surg Engl. 2014;96:156-9.

16. Gauvin DV, Abernathy MM, Tapp RL, Yoder JD, Dalton JA, Baird TJ. The failure to detect drug-induced sensory loss in standard preclinical studies. J Pharmacol Toxicol Methods. 2015;74:53-74.

17. Tuccori M, Lapi F, Testi A, et al. Drug-induced taste and smell alterations: a case/non-case evaluation of an Italian database of spontaneous adverse drug reaction reporting. Drug Saf. 2011;34(10):849-59.

18. Alatawi YM, Hansen RA. Empirical estimation of under-reporting in the US Food and Drug
Administration Adverse Event Reporting System (FAERS). Expert Opin Drug Saf. 2017;16(7):761-7.

19. Hazell L, Shakir SA. Under-reporting of adverse drug reactions: a systematic review. Drug Saf. 2006;29(5):385-96.

20. Murphy C, Schubert CR, Cruickshanks KJ, Klein BE, Klein R, Nondahl DM. Prevalence of olfactory impairment in older adults. JAMA. 2002;288(18):2307-12.

21. Wehling E, Nordin S, Espeseth T, Reinvang I, Lundervold AJ. Unawareness of olfactory dysfunction and its association with cognitive functioning in middle aged and old adults. Arch Clin Neuropsychol. 2011;26(3):260-9.

22. Lee WH, Wee JH, Kim DK, et al. Prevalence of subjective olfactory dysfunction and its risk factors: Korean National Health and Nutrition Examination Survey. PLoS One. 2013;8:e62725.

23. Michikawa T, Nishiwaki Y, Takebayashi T. Are you conscious of any age-related taste impairment? Prevalence of and factors associated with taste impairment in Japan. J Am Geriatr Soc. 2011;59(5):951-3.

24. Welge-Lussen A, Dorig P, Wolfensberger M, Krone F, Hummel T. A study about the frequency of taste disorders. J Neurol. 2011;258(3):386-92.

25. Fein BT, Kamin PB, Fein NN. The loss of smell in nasal allergy. Ann Allergy. 1966;24:278-83.

26. Cowart BJ, Flynn-Rodden K, McGeady SJ, Lowry LD. Hyposmia in allergic rhinitis. J Allergy Clin Immunol. 1993;91(3):747-51.

27. Stuck BA, Hummel T. Olfaction in allergic rhinitis: a systematic review. J Allergy Clin Immunol. 2015;136(6):1460-70.

28. Hoffman HJ, Cruickshanks KJ, Davis B. Perspectives on population-based epidemiological studies of olfactory and taste impairment. Ann N Y Acad Sci. 2009;1170:514-30.

29. Rydzewski B, Pruszewicz A, Sulkowski WJ. Assessment of smell and taste in patients with allergic rhinitis. Acta Otolaryngol. 2000;120(2):323-6.

30. Caster O, Edwards IR. Reflections on attribution and decisions in pharmacovigilance. Drug Saf. 2010;33(10):805-9.

31. Kuchen T, Straumann A, Safroneeva E, et al. Swallowed topical corticosteroids reduce the risk for long-lasting bolus impactions in eosinophilic esophagitis. Allergy. 2014;69(9):1248-54. 
32. Butz BK, Wen T, Gleich GJ, et al. Efficacy, dose reduction, and resistance to high-dose fluticasone in patients with eosinophilic esophagitis. Gastroenterology. 2014;147(2):324-33.

33. Andreae DA, Hanna MG, Magid MS, et al. Swallowed fluticasone propionate is an effective longterm maintenance therapy for children with eosinophilic esophagitis. Am J Gastroenterol. 2016;111(8):1187-97.

34. Tugrul S, Dogan R, Eren SB, Meric A, Ozturan O. The use of large volume low pressure nasal saline with fluticasone propionate for the treatment of pediatric acute rhinosinusitis. Int J Pediatr Otorhino Laryngol. 2014;78(8):1393-9.

35. Snidvongs $\mathrm{K}$, Thanaviratananich S. Update on intranasal medications in rhinosinusitis. Curr Allergy Asthma Rep. 2017;17(7):47.

36. Rawal S, Hoffman HJ, Bainbridge KE, Huedo-Medina TB, Duffy VB. Prevalence and risk factors of selfreported smell and taste alterations: results from the 2011-2012 US National Health and Nutrition Examination Survey (NHANES). Chem Senses. 2016;41(1):69-76.

37. Nordin S, Brämerson A. Complaints of olfactory disorders: epidemiology, assessment and clinical implications. Curr Opin Allergy Clin Immunol. 2008;8:10-5.

38. Boesveldt S, Postma EM, Boak D, et al. Anosmia-a clinical review. Chem Senses. 2017;42(7):513-23.

39. Doty RL, Bromley SM. Effects of drugs on olfaction and taste. Otolaryngol Clin $\mathrm{N}$ Am. 2004;37(6):1229-54.

40. Naik BS, Shetty N, Maben EV. Drug-induced taste disorders. Eur J Intern Med. 2010;21(3):240-3.

41. Apter AJ, Gent JF, Frank ME. Fluctuating olfactory sensitivity and distorted odor perception in allergic rhinitis. Arch Otolaryngol Head Neck Surg. 1999;125(9):1005-10.

42. Jankowski R, Klossek JM, Attali V, Coste A, Serrano E. Long-term study of fluticasone propionate aqueous nasal spray in acute and maintenance therapy of nasal polyposis. Allergy. 2009;64(6):944-50.

43. Vaidyanathan S, Barnes M, Williamson P, Hopkinson P, Donnan PT, Lipworth B. Treatment of chronic rhinosinusitis with nasal polyposis with oral steroids followed by topical steroids: a randomized trial. Ann Intern Med. 2011;154(5):293-302.
44. Penttilä M, Poulsen $P$, Hollingworth K, Holmström M. Dose-related efficacy and tolerability of fluticasone propionate nasal drops $400 \mathrm{mcg}$ once daily and twice daily in the treatment of bilateral nasal polyposis: a placebo-controlled randomized study in adult patients. Clin Exp Allergy. 2000;30(1):94-102.

45. Mygind N, Nielsen LP, Hoffmann HJ, et al. Mode of action of intranasal corticosteroids. J Allergy Clin Immunol. 2001;108(1 Suppl):S16-25.

46. Soler ZM, Sauer DA, Mace J, Smith TL. Relationship between clinical measures and histopathologic findings in chronic rhinosinusitis. Otolaryngol Head Neck Surg. 2009;141(4):454-61.

47. Soler ZM, Sauer DA, Mace J, Smith TL. Impact of mucosal eosinophilia and nasal polyposis on quality-of-life outcomes after sinus surgery. Otolaryngol Head Neck Surg. 2010;142:64-71.

48. Hauser LJ, Chandra RK, Li P, Turner JH. Role of tissue eosinophils in chronic rhinosinusitis-associated olfactory loss. Int Forum Allergy Rhinol. 2017. https://doi.org/10.1002/alr.21994.

49. Meltzer EO, Orgel HA, Rogenes PR, Field EA. Nasal cytology in patients with allergic rhinitis: effects of intranasal fluticasone propionate. J Allergy Clin Immunol. 1994;94(4):708-15.

50. Nielsen LP, Bjerke T, Christensen MB, et al. Eosinophil markers in seasonal allergic rhinitis. Intranasal fluticasone propionate inhibits local and systemic increases during the pollen season. Allergy. 1998;53(8):778-85.

51. Zhang X, Moilanen E, Kankaanranta H. Enhancement of human eosinophil apoptosis by fluticasone propionate, budesonide, and beclomethasone. Eur J Pharmacol. 2000;406(3):325-32.

52. Cavazzana A, Larsson $M$, Münch $M$, Hähner A, Hummel T. Post infectious olfactory loss: a retrospective study on 791 patients. Laryngoscope. 2017. https://doi.org/10.1002/lary.26606.

53. Welge-Lüssen A. Re-establishment of olfactory and taste functions. GMS Curr Top Otorhinolaryngol Head Neck Surg. 2005;4:Doc06.

54. Stuck BA, Fadel V, Hummel T, Sommer JU. Subjective olfactory desensitization and recovery in humans. Chem Senses. 2014;39(2):151-7.

55. Ajmani GS, Suh HH, Wroblewski KE, Pinto JM. Smoking and olfactory dysfunction: a systematic literature review and meta-analysis. Laryngoscope. 2017;127(8):1753-61. 
56. Hayes JE, Jinks AL. Evaluation of smoking on olfactory thresholds of phenyl ethyl alcohol and n-butanol. Physiol Behav. 2012;107(2):177-80.

57. Bousquet PJ, Cropet C, Klossek JM, Allaf B, Neukirch F, Bousquet J. Effect of smoking on symptoms of allergic rhinitis. Ann Allergy Asthma Immunol. 2009;103(3):195-200.

58. Lund VJ, Flood J, Sykes AP, Richards DH. Effect of fluticasone in severe polyposis. Arch Otolaryngol Head Neck Surg. 1998;124(5):513-8.

59. Keith P, Nieminen J, Hollingworth K, Dolovich J. Efficacy and tolerability of fluticasone propionate nasal drops 400 microgram once daily compared with placebo for the treatment of bilateral polyposis in adults. Clin Exp Allergy. 2000;30(10):1460-8.

60. Dijkstra MD, Ebbens FA, Poublon RM, Fokkens WJ. Fluticasone propionate aqueous nasal spray does not influence the recurrence rate of chronic rhinosinusitis and nasal polyps 1 year after functional endoscopic sinus surgery. Clin Exp Allergy. 2004;34(9):1395-400.

61. Blomqvist EH, Lundblad L, Bergstedt H, Stjärne P. Placebo-controlled, randomized, double-blind study evaluating the efficacy of fluticasone propionate nasal spray for the treatment of patients with hyposmia/anosmia. Acta Otolaryngol. 2003;123(7):862-8.

62. Aukema AA, Mulder PG, Fokkens WJ. Treatment of nasal polyposis and chronic rhinosinusitis with fluticasone propionate nasal drops reduces need for sinus surgery. J Allergy Clin Immunol. 2005;115(5):1017-23.

63. Rowe-Jones JM, Medcalf M, Durham SR, Richards DH, Mackay IS. Functional endoscopic sinus surgery: 5 year follow up and results of a prospective, randomised, stratified, double-blind, placebo controlled study of post-operative fluticasone propionate aqueous nasal spray. Rhinology. 2005;43(1):2-10.

64. Demirel T, Orhan KS, Keleş N, Değer K. Comparison of the efficacy of nasal drop and nasal spray applications of fluticasone propionate in nasal polyps. Kulak Burun Bogaz Ihtis Derg. 2008;18(1):1-6.

65. Vlckova I, Navrátil P, Kana R, Pavlicek P, Chrbolka P, Djupesland PG. Effective treatment of mild-tomoderate nasal polyposis with fluticasone delivered by a novel device. Rhinology. 2009;47(4):419-26.

66. Olsson P, Ehnhage A, Nordin S, Stjarne P, NAF2S2 Study Group. Quality of life is improved by endoscopic surgery and fluticasone in nasal polyposis with asthma. Rhinology. 2010;48(3):325-30.
67. Ye P, Shi L, Zhang QL, Li ZX, Pan LX, Cai LX, Feng $X$, Huang Q, Zhou B, Jin P. Subjective improvement of olfactory function after endoscopic sinus surgery for chronic rhinosinusitis. Eur J Allergy Clin Immunol. 2015; 70:Suppl. 101 626. https://doi.org/ 10.1111/all.12724.

68. Klimek L, Poletti SC, Sperl A, et al. Olfaction in patients with allergic rhinitis: an indicator of successful MP-AzeFlu therapy. Int Forum Allergy Rhinol. 2017;7(3):287-92.

69. Saunders MW, Wheatley AH, George SJ, Lai T, Birchall MA. Do corticosteroids induce apoptosis in nasal polyp inflammatory cells? In vivo and in vitro studies. Laryngoscope. 1999;109(5):785-90.

70. Johansen VL, Illum P, Kristensen S, Winther L, Vang Petersen S, Synnerstad B. The effect of budesonide (Rhinocort) in the treatment of small and medium-sized nasal polyps. Clin Otolaryngol Allied Sci. 1993;18:524-7.

71. Lildholdt T, Rundcrantz H, Lindqvist N. Efficacy of topical corticosteroid powder for nasal polyps: a double-blind, placebo-controlled study of budesonide. Clin Otolaryngol Allied Sci. 1995;20:26-30.

72. Tos M, Svendstrup F, Arndal H, et al. Efficacy of an aqueous and a powder formulation of nasal budesonide compared in patients with nasal polyps. Am J Rhinol. 1998;12:183-9.

73. Filiaci F, Passali D, Puxeddu R, Schrewelius C. A randomized controlled trial showing efficacy of once daily intranasal budesonide in nasal polyposis. Rhinology. 2000;38:185-90.

74. Jankowski R, Schrewelius C, Bonfils P, et al. Efficacy and tolerability of budesonide aqueous nasal spray treatment in patients with nasal polyps. Arch Otolaryngol Head Neck Surg. 2001;127:447-52.

75. Small CB, Hernandez J, Reyes A, et al. Efficacy and safety of mometasone furoate nasal spray in nasal polyposis. J Allergy Clin Immunol. 2005;116:1275-81.

76. Stjarne $\mathrm{P}$, Mosges $\mathrm{R}$, Jorissen $\mathrm{M}$, et al. A randomized controlled trial of mometasone furoate nasal spray for the treatment of nasal polyposis. Arch Otolaryngol Head Neck Surg. 2006;132:179-85.

77. Stjarne P, Blomgren K, Caye-Thomasen P, Salo S, Soderstrom T. The efficacy and safety of once-daily mometasone furoate nasal spray in nasal polyposis: a randomized, double-blind, placebo-controlled study. Acta Otolaryngol. 2006;126:606-12.

78. Stjarne P, Olsson P, Alenius M. Use of mometasone furoate to prevent polyp relapse after endoscopic 
sinus surgery. Arch Otolaryngol Head Neck Surg. 2009; 135:296-302.

79. Jorissen M, Bachert C. Effect of corticosteroids on wound healing after endoscopic sinus surgery. Rhinology. 2009;47:280-6.

80. Sivam A, Jeswani S, Reder L, et al. Olfactory cleft inflammation is present in seasonal allergic rhinitis and is reduced with intranasal steroids. Am J Rhinol Allergy. 2010;24(4):286-90.

81. Cassidy B, McCoy DG. The sweet smell of success. Anaesthesia. 2000;55(8):823.

82. Miguel D, Darr-Foit S, Tittelbach J, Elsner P. Trigeminal neuropathy responding to systemic corticosteroids and methotrexate in a patient with diffuse cutaneous systemic sclerosis. Eur J Dermatol. $2017 ; 27(1): 82-3$.
83. Ikeda K, Sakurada T, Suzaki Y, Takasaka T. Efficacy of systemic corticosteroid treatment for anosmia with nasal and paranasal sinus disease. Rhinology. 1995;33(3):162-5.

84. Ikeda K, Sakurada T, Takasaka T, Okitsu T, Yoshida S. Anosmia following head trauma: preliminary study of steroid treatment. Tohoku J Exp Med. 1995;177(4):343-51.

85. Jiang RS, Wu SH, Liang KL, Shiao JY, Hsin CH, Su MC. Steroid treatment of posttraumatic anosmia. Eur Arch Otorhinolaryngol. 2010;267(10):1563-7.

86. Jiang RS, Twu CW, Liang KL. Medical treatment of traumatic anosmia. Otolaryngol Head Neck Surg. 2015;152(5):954-8. 